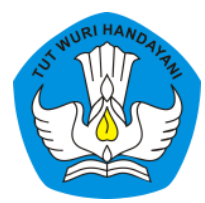

\title{
LARI MESI ALTERNATIF PENANAMAN KESADARAN KONSTITUSI DAN SIKAP TOLERANSI BAGI PESERTA DIDIK SEKOLAH DASAR
}

\section{Hendrik Hermawan}

Sekolah Dasar Negeri 1 Wirosari, Grobongan, Jawa Tengah, Indonesia Contributor Email: hendrikhermawan84@gmail.com

Article Url: https:// ojsdikdas.kemdikbud.go.id/index.php/didaktika/article/view/353

\begin{abstract}
The purpose of implementing this learning is to instill constitutional awareness and tolerance for fourth grade students at the Wirosari 1 State Elementary School in 2020/2021 by using the Lari Mesi media. The type of scientific innovation used is the best practice method by testing the effectiveness of the Lari Mesi multimedia by analyzing the increase in constitutional awareness after and during learning. There was an increase in constitutional awareness of learning outcomes and observations from before using the Lari Mesi media to after using it, from only $30 \%$ of students who completed it to $89.71 \%$ who completed it.
\end{abstract}

Keywords: Lari Mesi; Constitutional Awareness; Tolerance Attitude; Citizenship Education. 


\begin{abstract}
Abstrak
Tujuan pelaksanaan pembelajaran ini adalah untuk menanamkan kesadaran konstitusi dan sikap toleransi peserta didik kelas IV Sekolah Dasar Negeri 1 Wirosari Tahun 2020/2021 dengan menggunakan media Lari Mesi. Jenis karya ilmiah inovasi yang digunakan adalah menggunakan metode best practice dengan menguji keefektifan multimedia Lari Mesi dengan menganalisis peningkatan kesadaran berkonstitusi setelah dan selama pembelajaran. Terjadi peningkatan kesadaran berkonstitusi dari hasil belajar dan observasi dari sebelum menggunakan menggunakan media Lari Mesi dengan sesudah menggunakannya, dari hanya 30\% siswa yang tuntas menjadi 89,71\% yang tuntas.
\end{abstract}

Kata Kunci: $\quad$ Lari Mesi; Kesadaran Konstitusi; Sikap Toleransi; Pendidikan Kewarganegaraan.

\title{
A. Pendahuluan
}

Pembelajaran Pendidikan Kewarganegaraan (PKn) di Sekolah Dasar (SD) bermuara pada penciptaan manusia seutuhnya dan seluruhnya sebagai warga negara Indonesia yang baik dan memiliki pengetahuan kebangsaan (civics virtue). Pembelajaran Pendidikan Kewarganegaraan (PKn) bertujuan agar seluruh elemen berperan serta dalam mengembangkan nilai-nilaiP dan Undang-Undang Dasar Negara Kesatuan Republik Indonesia Tahun 1945. Maka peran guru kelas yang mengajar mata pelajaran Pendidikan Kewarganegaraan (PKn) menjadi sangat penting seiring dengan bertambah kompleksnya permasalahan yang berkaitan konstitusi Negara Indonesia.

Sekolah Dasar (SD) 1 Wirosari merupakan salah satu sekolah yang berada di Kabupaten Grobogan dengan kondisi masyarakat yang mayoritas bekerja sebagai petani dan karyawan swasta. Hal ini secara tidak langsung menyebabkan perhatian orang tua pada peserta didik dalam pembelajaran menjadi kurang optimal. Meskipun sebagian peserta didik mempunyai kemampuan dalam menyerap pelajaran yang tinggi, masih banyak peserta didik yang mempunyai kemampuan dalam menyerap pelajaran yang rendah. Hal ini dapat dapat dilihat dari rendahnya persentase peserta didik yang mencapai batas Kriteria Ketuntasan Minimal (KKM). Berdasarkan data nilai peserta didik pada mata pelajaran Pendidikan Kewarganegaraan (PKn), hanya 10 peserta didik dari total 38 peserta didik yang mencapai ketuntasan seperti yang tersaji pada Tabel 1. 
Hendrik Hermawan

Tabel Error! No text of specified style in document.. Data Nilai Peserta Didik Pelajaran PKn

\begin{tabular}{ccccc}
\hline No & Interval Nilai & Frekuensi & Prosentase & Rata-rata Nilai \\
\hline 1 & $0-59$ & 17 & $45 \%$ & \\
2 & $60-69$ & 11 & $29 \%$ & 56,84 \\
3 & $70-79$ & 10 & $26 \%$ & \\
6 & $80-89$ & 0 & $0 \%$ & \\
5 & $90-100$ & 0 & $0 \%$ & \\
& Jumlah & 38 & $100 \%$ & \\
\hline
\end{tabular}

Berdasarkan data nilai peserta didik pelajaran PKn yang tersaji pada Tabel 1 di atas, dapat dijelaskan bahwa nilai peserta didik pada pelajaran PKn, berada di bawah 80 . Rinciannya adalah nilai 0-59 berjumlah 17 peserta didik (45\%); 60-69 berjumlah 11 peserta didik (29\%); dan 70-79 berjumlah 10 peserta didik (26\%). Data ini menunjukkan bahwa pembelajaran PKn di SD Negeri 1 Wirosari perlu ditingkatkan. Salah satu upaya dalam meningkatkan nilai peserta didik tersebut adalah dengan menggunakan media ataupun metode yang sesuai dengan karakteristik peserta didik. Peran seorang guru dalam hal ini sangat penting. Hal ini sesuai dalam Peraturan Menteri Pendidikan Nasional (Permendiknas) Republik Indonesia Nomor 41 Tahun 2007, yang menuntut seorang guru untuk menjadi agen perubahan yang selalu memberi dukungan pada peserta didik dalam melaksanakan pendidikannya untuk membangun aspek-aspek dalam dirinya yaitu kognitif, afektif maupun psikomotorik melalui sebuah proses belajar yang aktif, kreatif, efektif, dan menyenangkan (BSNP, 2007).

Kecenderungan seorang anak saat ini adalah bermain games baik di Handphone (HP) maupun dengan mesin Play Station (PS). Anak-anak merasa tertantang untuk terus bermain dengan level yang meningkat bahkan bisa menghabiskan waktu berjam-jam sehingga mereka lupa waktu untuk belajar. Dampak bermain game ini merugikan anak-anak karena anak-anak lebih termotivasi untuk bermain daripada belajar. Padahal, tidak dapat dipungkiri 
bahwa banyak game yang dibuat oleh negara asing dengan isi (konten) kekerasan, seksual, bahkan sikap-sikap intoleran.

Fenomena ketertarikan peserta didik terhadap game edukasi yang membangun kecerdasan mendorong penulis untuk mengembangkan game yang dapat digunakan untuk meni menumbuhan kesadaran konstitusidalam pelajaran PKn di Sekolah dasar. Dengan demikian, peserta didik dapat diharapkan tidak lagi memandang PKn sebagai hafalan semata. Pelaksanaan pembelajaran PKn di SD Negeri 1 Wirosari, tempat penulis bertugas, harus lebih inovatif agar dapat diterima oleh peserta didik dengan baik. Apalagi mengingat media, metode, dan pendekatan yang konvensional yang ada saat ini kurang bisa meningkatkan hasil belajar peserta didik tentang kesadaran konstitusi.

Lari Mesi adalah akronim dari "Lagu Tari dan Games Edukasi" sebuah kombinasi yang integral antara pendidikan afektif kognitif dan psikomotorik yang disukai oleh peserta didik. Games Edukasi adalah sebuah games yang di dalamnya bersifat mendidik dan memiliki fungsi sebagai media pembelajaran yang diciptakan dari piranti lunak baik Adobe Animated CC dan Adobe Audition CC dengan harapan peserta didik dapat belajar sambil bermain. Aplikasi yang kemudian disingkat sebagai Lari Mesi merupakan games edukasi yang di dalamnya berisi tari lagu anak sebagai pembuka dilanjutkan dengan games anak yang berisi konten Pendidikan Kewarganegaraan terutama penumbuhan konstitusi dan sikap toleransi. Lari Mesi dapat digunakan untuk enumbuhkan kesadaran konstitusi dan sikap toleransi sekaligus menciptakan pembelajaran yang menyenangkan, aktif, kreatif, dan inovatif bagi peserta didik; menjadi bahan peningkatan kompetensi dan kinerja guru dalam menciptakan pembelajaran yang PAIKEM dalam Pendidikan Kewarganegaraan (PKn) serta bermakna bagi siswa sekaligus mengembangkan profesi sebagai guru PKn profesional; serta menjadi bahan referensi kepala sekolah dalam menyusun kebijakan sekolah terutama dalam untuk 
menumbuhkan kesadaran konstitusi dan sikap toleransi melalui pelajaran Pendidikan Kewarganegaraan.

\section{B. Metode}

Strategi peningkatan kesadaran konstitusi dan sikap toleransi dengan menerapkan Lari Mesi di SD Negeri 1 Wirosari. Dengan tahapan operasional pelaksanaaan seperti tampak pada Tabel 2.

Tabel 2. Tahapan Operasional

\begin{tabular}{|c|c|c|c|}
\hline Strategi & Perencanaan & Pelaksanaan & Keterangan \\
\hline $\begin{array}{l}\text { Menyiapkan media } \\
\text { dan perangkat pembe- } \\
\text { lajaran untuk penum- } \\
\text { buhan kesadaran } \\
\text { berkonstitusi }\end{array}$ & $\begin{array}{l}\text { 1. Membuat media } \\
\text { 2. Melakukan uji } \\
\text { media dan RPP }\end{array}$ & $\begin{array}{l}\text { Menguji di Formulasi } \\
\text { dan } \\
\text { verifikasi RPP }\end{array}$ & $\begin{array}{l}\text { Tahun Pelajaran } \\
\text { 2020/2021 }\end{array}$ \\
\hline \multirow[t]{2}{*}{$\begin{array}{l}\text { Memahami } \\
\text { Konstitusi pasal 28- } \\
32 \text { dan nilai juang } \\
\text { Pancasila }\end{array}$} & $\begin{array}{l}\text { Program pembelajaran } \\
\text { pegembangan dalam } \\
\text { Rencana Pelaksanaan } \\
\text { Pembelajaran (RPP) }\end{array}$ & Pembelajaran & $\begin{array}{l}\text { Tahun Pelajaran } \\
\text { 2020/2021 }\end{array}$ \\
\hline & $\begin{array}{l}\text { Program kegiatan } \\
\text { diluar pembelajaran }\end{array}$ & $\begin{array}{l}\text { 1. Menggunakan } \\
\text { perpustakaan } \\
\text { sebagai pembiasaan } \\
\text { 2. Membina kegiatan } \\
\text { ekstra kurikuler }\end{array}$ & $\begin{array}{l}\text { Tahun Pelajaran } \\
2020 / 2021\end{array}$ \\
\hline $\begin{array}{l}\text { Menerapkan Lari } \\
\text { Mesi sebagai tugas } \\
\text { terstruktur dan tak } \\
\text { terstruktur }\end{array}$ & $\begin{array}{lr}\text { Sebagai } & \text { tugas } \\
\text { terstruktur } & \text { peserta } \\
\text { didik } & \end{array}$ & Di rumah & $\begin{array}{l}\text { Tahun Pelajaran } \\
\text { 2020/2021 }\end{array}$ \\
\hline
\end{tabular}

Tahapan awal pembuatan media Lari Mesi pada dasarnya adalah membuat lagu dan tari terlebih dahulu, kemudian memasukkan dalam game seperti pada Gambar 1. Proses produksi pembuatan game Lari Mesi dengan mengacu tahapan menurut Ivan C (2009) yaitu (1) memilih genre dan materi dalam game. Genre dalam game merupakan tema dasar dalam pengembangan game yang juga mempunyai fungsi sebagai tujuan pemanfaatan game; (2) Menentukan tool. Tool dianggap sebagai tangan dan kelengkapan dalam menjalankan game tersebut agar dapat diberikan konten pembelajaran PKn; (3) Menentukan Game Play. Game Play diartikan sebagai aturan yang akan dipakai agar permainan berlangsung dengan benar; (4) Menentukan Grafis. Di dalam penentuan grafis diusahakan agar sesuai dengan konten anak agar nyaman bila dilihat dan dimainkan; (5) 
Menentukan suara. Suara yang digunakan sebagai pengisi suara diusahakan suara yang akrab bagi anak yaitu suara anak sehingga pemain game dapat merasakan realistisnya setiap permainan yang ada; (6) Pembuatan game. Pembuatan game dilakukan dengan prinsip dari anak, oleh anak, untuk anak. Artinya pengisian lagu dan tari dibantu oleh anak agar merasa dilibatkan dan memiliki perasaan memiliki dalam game tersebut; (7) Publishing game. Publishing merupakan bagian dimana game diujicobakan pada peserta didik lain ataupun pakar multimedia (Gambar 2) yang memahami bagaimana konsep game terbaik dibuat dan bagaimana mengombinasikan setiap elemen yang ada.

Beberapa proses tersebut dapat diamati pada gambar 1 dan 2 berikut.

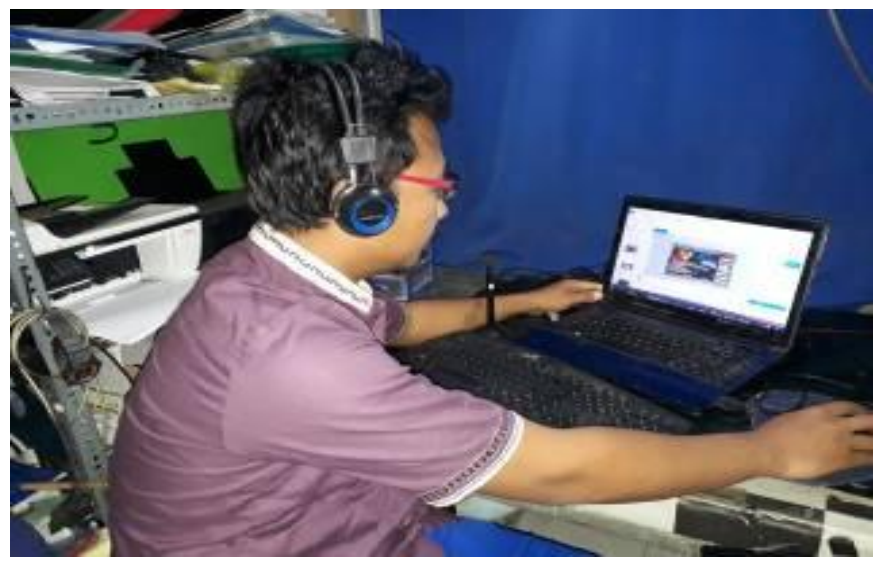

Gambar 1. Proses Produksi Games Lari Mesi

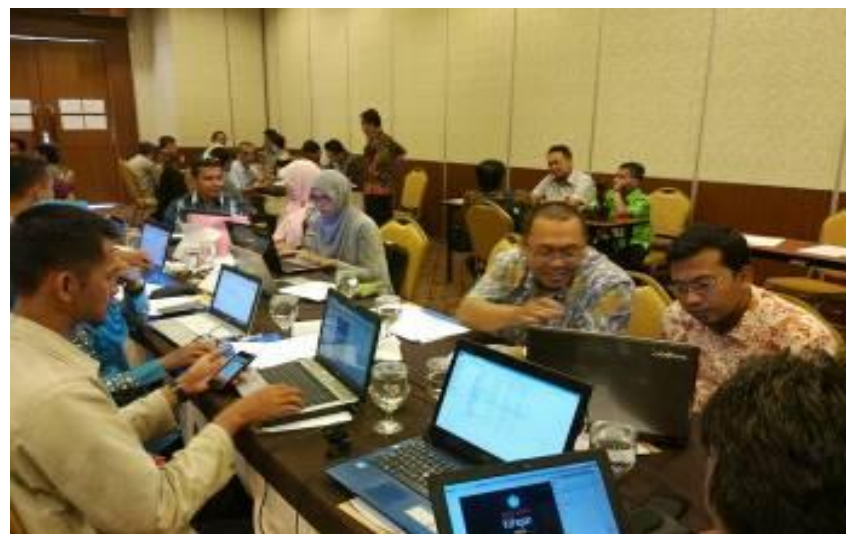

Gambar 2. Konsultasi dengan Pakar Media 


\section{Hasil dan Pembahasan}

Nilai-nilai Pancasila dan sikap toleransi tidak hanya dimiliki oleh orang dewasa, namun semua kalangan wajib memilikinya, tak terkecuali anak-anak. Nilai-nilai Pancasila dan sikap toleransi harus ditanamkan sejak dini. Nilai-nilai Pancasila dan sikap toleransi harus dimiliki sejak kecil untuk menumbuhkan sikap cinta tanah air dan memberikan wawasan berkaitan pendidikan kewarganegaraan kepada anak-anak. Nilai-nilai Pancasila dan sikap toleransi diajarkan pula oleh penulis kepada peserta didik di sekolahnya. Pengajaran nilai-nilai Pancasila dan sikap toleransi di wilayah penulis memiliki beberapa tantangan.

SD Negeri 1 Wirosari yang terletak cukup jauh dari lingkungan perkotaan maupun kabupaten. Ini merupakan salah satu tantangan yang dihadapi oleh penulis. Selain itu, kondisi peserta didik juga cukup beragam. Selama ini, proses pembelajaran berlangsung dengan kondusif. Namun, sebagai seorang guru, penulis senantiasa mencoba untuk lebih kreatif dan inovatif dengan lebih meningkatkan kualitas pembelajaran. Hal ini penulis lakukan dengan menerapkan Lari Mesi yaitu akronim dari lagu tari dan Games Android untuk meningkatkan kesadaran konstitusi dan sikap toleransi di SD Negeri 1 Wirosari. Penulis menggabungkan pembelajaran secara kognitif afektif dan psikomotorik secara bersama yaitu menyanyi menari serta games sebagai psikomotorik, sikap toleransi sebagai afektif, dan materi PKn sebagai kognitif. Melalui penggabungan pembelajaran tersebut diharapkan peserta didik memiliki kesadaran konstitusi dan sikap toleransi. Apabila kesadaran konstitusi dan sikap toleransi telah mengalami

peningkatan dan proses pembelajaran menjadi lebih menarik, maka akan memberi inspirasi guru lain untuk melakukan hal yang sama.

\section{Menciptakan Lagu Tari di Games Edukasi}

Tahapan awal yang dilakukan penulis yaitu dengan menciptakan lagu tari di games edukasi. Proses menciptakan lagu tari di games edukasi, penulis mengkreasikan lagu dan tari dengan tema toleransi dan mengingat konstitusi 
Undang-Undang Dasar Negara Kesatuan Republik Indonesia. Gerakan tari dalam irama lagu ini disusun dengan menyesuaikan minat peserta didik. Hal ini bertujuan agar peserta didik mudah dalam mengingat gerakan tari tersebut. Lagu yang digunakan dalam games edukasi merupakan gubahan nada dari lagu daerah atau lagu nasional Indonesia. Harapannya peserta didik memiliki rasa cinta tanah air dan budaya bangsa Indonesia.

Penulis merancang konsep aplikasi dengan mengadopsi games secara umum dengan memasukkan berbagai konten Pendidikan Kewarganegaraan (PKn). Tokoh dalam aplikasi ini dibuat dengan menggunakan Adobe Illustrator. Adobe Ilustrator adalah program editor grafis vektor terkemuka. Adobe Ilustrator ini dikembangkan dan dipasarkan oleh Adobe Systems. Adobe Illustrator CC merupakan versi terkini dari program Adobe Illustrator. Lagu dan tari merupakan bagian pengantar dalam sebuah aplikasi Android. Aplikasi android ini menggunakan Adobe Animated CC. Adobe Animated merupakan multimedia yang berguna untuk membuat animasi dari Adobe Systems. Adobe Animated ini digunakan untuk merancang grafik vektor dan animasi untuk program televisi, video online, situs web, aplikasi web, aplikasi internet, dan permainan video. Penulis memanfaatkan Adobe Animated ini untuk permainan video. Penulis memadukan tampilan karakter dengan Adobe Illustrator yang diolah menjadi sebuah game menggunakan Adobe Animated CC.

Hal ini seperti yang terlihat pada tampilan Gambar 3. 


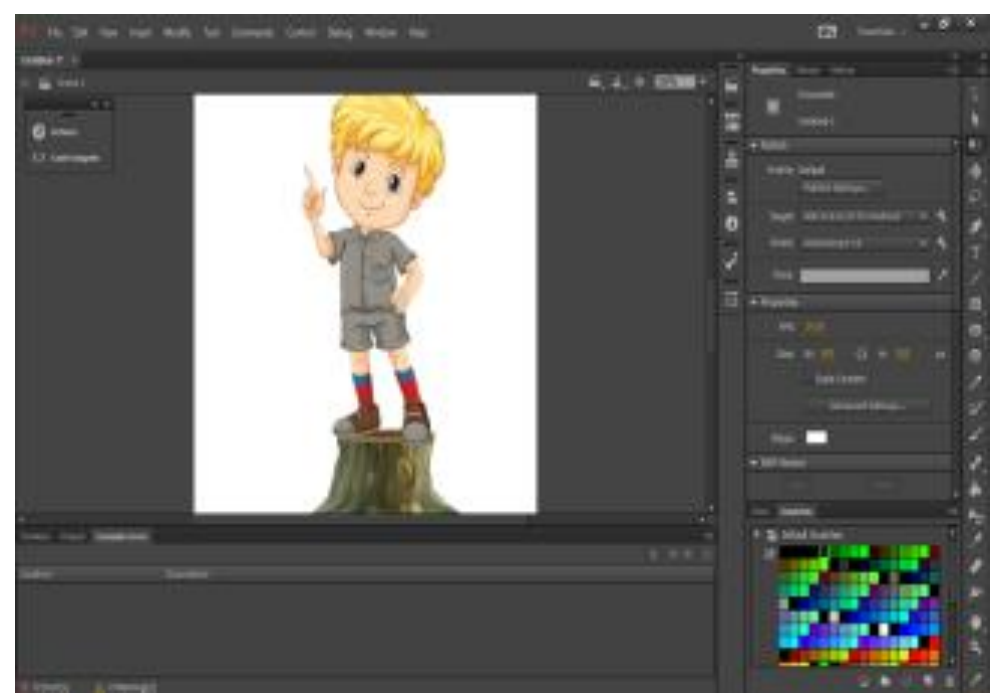

Gambar 3. Tampilan Karakter dengan Adobelllustrator yang Diolah Menjadi Game Menggunakan Adobe Animated CC

Selain itu, dalam games ini juga digunakan software Articulate Storyline. Articulate Storyline adalah sebuah perangkat lunak yang dapat digunakan untuk membuat presentasi. Articulate Storyline ini memiliki fungsi yang sama dengan Microsoft Power Point. Namun, Articulate Storyline memiliki beberapa kelebihan sehingga dapat menghasilkan presentasi yang lebih komprehensif dan kreatif. Software ini juga memiliki fitur-fitur seperti timeline,movie, picture, character, dan lain-lain yang mudah digunakan. Tampilan Articulate Storyline seperti yang terlihat pada Gambar 4. 


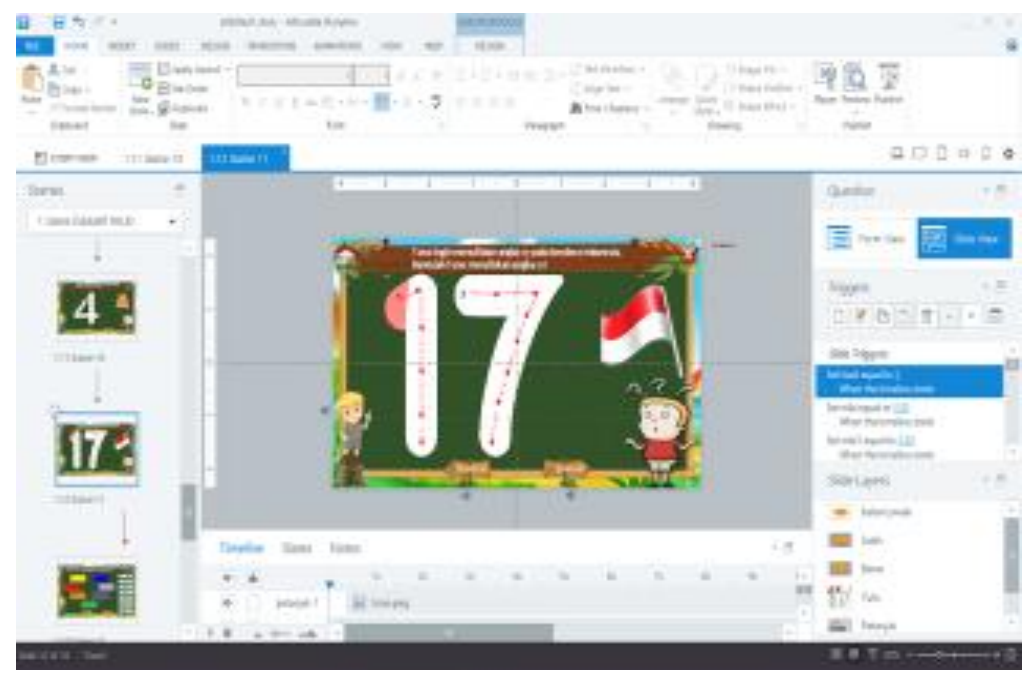

Gambar 4. Tampilan Software Articulate Storyline

Lagu dalam games ini dikreasikan menggunakan Adobe Audition. Adobe Audition merupakan software komputer yang dikenal sebagai penyunting audio atau suara. Perangkat lunak ini memiliki fitur-fitur profesional dalam hal melakukan editing mixing dan mastering audio. Adobe Audiion ini juga merupakan perangkat lunak profesional yang menjadi pilihan utama bagi para pengguna untuk mengolah kualitas suara maupun audio, seperti perekaman, musik, instrumen, radio, proyek podcast dan lainnya. Terlihat pada gambar, penulis sedang membuat media menggunakan Adobe Audition pada Gambar 5. 


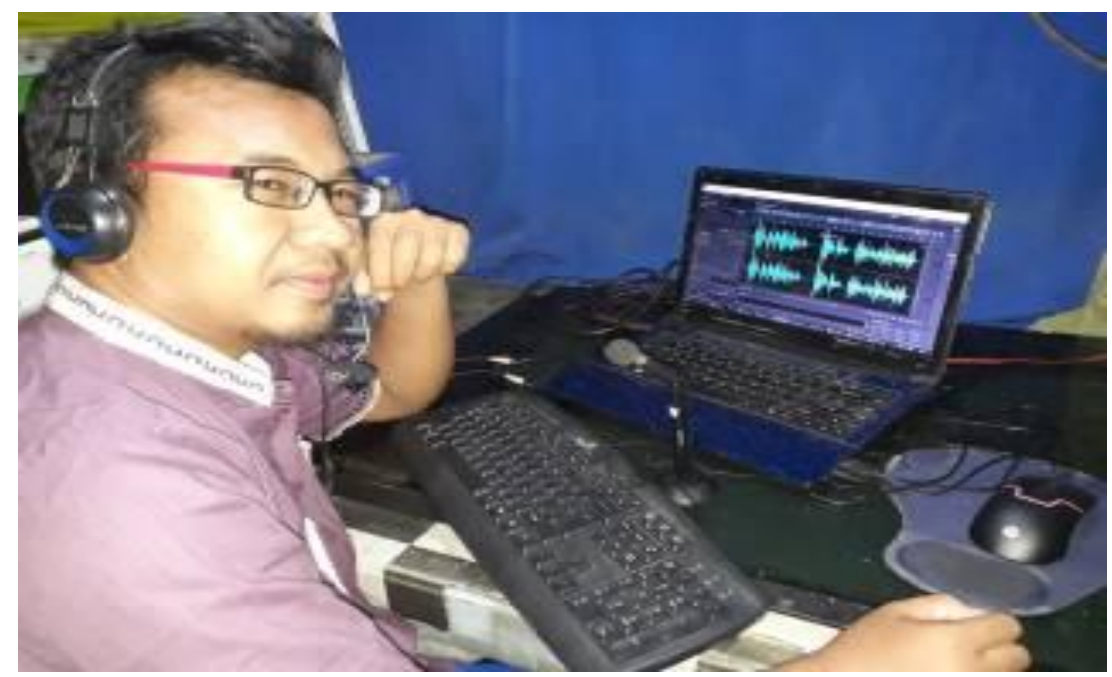

Gambar 5. Pembuatan Media Menggunakan Adobe Audition

Pembuatan media dilaksanakan bersama peserta didik terutama dalam lagu dan tari. Pelibatan peserta didik ini bertujuan agar peserta didik dapat memahami proses pembuatan media. Untuk aplikasi android, penulis membuat secara hati-hati, kemudian memasukkan suara agar terkesan lebih natural. Setelah itu, dilakukan pengubahan format disesuaikan dengan format telepon genggam (HP) agar portable/ dapat digunakan dan bisa dibuka oleh peserta didik tanpa ada batasan waktu dan tempat.

\section{Uji Kelayakan Media}

Setelah menciptakan lagu tari di games edukasi, langkah selanjutnya adalah uji kelayakan media. Kegiatan uji kelayakan media in bertujuan untuk mengukur tingkat kelayakan media yang digunakan dalam pembelajaran. Kegiatan ini dilaksanakan oleh praktisi multimedia yang berasal dari Provinsi Jawa Tengah. Praktisi tersebut tergabung dalam Formulasi. Beliau adalah salah satu guru dari Kabupaten Grobogan, bernama Dona Agus Setiyawan, pada tahun 2015 menjadi Juara 1 Pembuatan Media Pembelajaran Berbasis Komputer tingkat Jawa Tengah. Beliau juga merupakan anggota formulasi dan menjadi penguji dalam uji kelayakan media. Uji kelayakan media ini ditinjau dari beberapa kriteria. Kriteria dan hasil uji kelayakan media ini seperti yang tersaji dalam Tabel 3. 
Tabel 3. Kriteria Kelayakan Media Lari Mesi

\begin{tabular}{clcl}
\hline No & \multicolumn{1}{c}{ Kriteria } & Skor & \multicolumn{1}{c}{ Kategori } \\
\hline 1 & Tujuan media ini sangat Jelas & 5,0 & Sangat Kuat \\
2 & Kedalaman materi media & 5,0 & Sangat Kuat \\
3 & Isi materi sesuai dengan kebenaran & 4,0 & Kuat \\
4 & Bersifat komunikatif & 5,0 & Sangat Kuat \\
5 & Evaluasi sesuai tujuan dan materi & 4,0 & Kuat \\
6 & Media Ini mudah digunakan oleh khalayak umum & 4,0 & Kuat \\
\hline
\end{tabular}

Berdasarkan Tabel 3 di atas, dapat diketahui media Lari mesi mendapat penilaian (1) sangat kuat atau memiliki skor 5,0 pada tujuan media sangat jelas, kedalaman materi media, dan bersifat komunikatif; (2) kuat atau memiliki skor 4,0 pada isi materi sesuai dengan kebenaran, evaluasi sesuai tujuan dan materi, dan mudah digunakan khalayak umum. Berdasarkan penilaian tersebut, dapat diketahui bahwa media Lari mesi secara keseluruhan mendapatkan penilaian kuat dan sangat kuat. Oleh karena itu, media ini layak digunakan dalam proses pembelajaran Pendidikan Kewarganegaraan (PKN) berbasis media.

\section{Verifikasi Rencana Pelaksanaan Pembelajaran}

Setelah dilakukan uji kelayakan media, langkah selanjutnya adalah melakukan verifikasi rencana pelaksanaan pembelajaran. Rencana pelaksanaan pembelajaran disusun dengan langkah-langkah (1) pada kegiatan awal, peserta didik diberikan apersepsi tentang materi yang akan dipelajari; (2) pada kegiatan inti peserta didik diajak melakukan tanya jawab dan merumuskan beberapa pertanyaan dan jawaban; (3) peserta didik diajak bermain games Lari Mesi, kemudian peserta didik melakukan diskusi dan mempresentasikan hasil diskusi; (4) pada kegiatan akhir peserta didik diajak mengulang beberapa lagu tarian serta melakukan refleksi terhadap games android yang dimainkan.

Keseluruhan rencana pembelajaran tersebut kemudian diverifikasi oleh rekan sejawat yaitu Retno Tyas Utami, S.Pd., M.Pd., dan Purwanto, S.Pd., M.Pd., dalam lingkup Sekolah Dasar (SD) di Kecamatan Wirosari. Hasil verifikasi menunjukkan beberapa hal harus direvisi dan mendapat masukan untuk memperbaiki kegiatan inti. 


\section{Uji Coba Pembelajaran Pendidikan Kewarganegaraan dengan Media Lari Mesi}

Setelah proses verifikasi Rencana Pelaksanaan Pembelajaran, langkah selanjutnya adalah melaksanakan pembelajaran Pendidikan Kewarganegaraan yang menanamkan kesadaran berkonstitusi pasal 29-32 dan sikap toleransi. Pembelajaran untuk menanamkan kesadaran berkonstitusi dilaksanakan di dalam kelas di SD Negeri 1 Wirosari. Hasil pembelajaran ini nantinya akan dibandingkan dengan hasil pembelajaran dengan menggunakan media Lari Mesi dan dengan menggunakan media Lari Mesi. Pelaksanaan pembelajaran tertuang pada Tabel 4 .

Tabel 4. Jadwal Pelaksanaan Pembelajaran PKn

\begin{tabular}{lcc}
\hline No & Hari/ tanggal & Kegiatan \\
\hline 1. & Rabu, 1 Agustus 2020 & Tanpa Menggunakan Media Lari Mesi \\
2 & Rabu, 8 Agustus 2020 & Dengan Menggunakan Media Lari Mesi \\
\hline
\end{tabular}

Berdasarkan jadwal pelaksanaan pembelajaran PKn yang tertuang pada tabel 4, hari Rabu tanggal 1 Agustus 2020 dilakukan kegiatan pembelajaran tanpa menggunakan Lari Mesu dan pada hari Rabu. tanggal 8 Agustus dilakukan kegiatan pembelajaran dengan menggunakan Lari Mesi.

\section{Desain Pelaksanaan Pembelajaran}

Peserta didik SD Negeri 1 Wirosari berjumlah 242 anak yang terdiri mulai dari kelas I sampai dengan kelas VI dengan masing-masing kelas terdiri 1 kelas. Masing-masing kelas diampu oleh guru kelas sebanyak 6 guru yaitu 1 guru Pendidikan Agama Islam, dan 1 guru Pendidikan Jasmani. Kondisi sosial ekonomi orang tua murid rata-rata cukup beragam. Guruguru bersemangat dalam pengabdiannya demi kemajuan anak didiknya. Peserta didik kelas IV SD Negeri 1 Wirosari berjumlah 38 peserta didik.

Tahapan-tahapan pelaksanaan pembelajaran di kelas adalah (1) permintaan izin di SD Negeri 1 Wirosari kepada Kepala Sekolah, (2) observasi dan wawancara untuk mendapatkan gambaran tentang peserta didik kelas IV SD Negeri 1 Wirosari secara keseluruhan, (3) identifikasi masalah (bersifat konvensional menggunakan hafalan dengan peserta didik yang memerlukan 
metode dan media menarik sehingga pembelajaran berlangsung secara menarik), dan (4) menyusun rencana pembelajaran secara menyeluruh untuk melaksanakan pembelajaran yang baik dan efektif.

\section{Deskripsi Pelaksanaan Pembelajaran dalam Membina Konstitusi dan Toleransi}

Pelaksanaan pembelajaran dalam membina konstitusi dan toleransi pada pertemuan pertama hari Rabu tanggal 1 Agustus 2018 penulis mengajar mata pelajaran PKn untuk menanamkan kesadaran konstitusi dan sikap toleransi. Penulis belum menggunakan multimedia Lari Mesi dan pelaksanaan pembelajaran didominasi ceramah.

Hasil observasi pada pembelajaran pertemuan pertama berkaitan dengan hasil belajar peserta didik tanpa multimedia Lari Mesi tersaji pada Tabel 5.

Tabel 5. Distribusi Hasil Belajar Peserta Didik Tanpa Multimedia Lari Mesi

\begin{tabular}{lcccc}
\hline \multicolumn{1}{c}{ Kategori } & Rentang Nilai & Frekuensi & Prosentase & Keterangan \\
\hline Sangat Tinggi & $90-100$ & 0 & $0 \%$ & Tuntas \\
Tinggi & $80-89$ & 6 & $16 \%$ & \\
Sedang & $70-79$ & 11 & $29 \%$ & \\
Rendah & $60-69$ & 15 & $39 \%$ & Tidak tuntas \\
Sangat Rendah & $0-59$ & 6 & $16 \%$ & \\
Jumlah & & 38 & $100 \%$ & \\
\hline
\end{tabular}

Berdasarkan Tabel 5, dapat dijelaskan bahwa hasil belajar peserta didik pertemuan pertama dari 38 peserta didik kelas IV. Hasilnya, ada 17 peserta didik $(45 \%)$ tuntas belajar sesuai dengan KKM dan 21 peserta didik (55\%) belum tuntas belajar sesuai dengan KKM. Tdak ada peserta didik yang memperoleh nilai pada rentang skor 90-100 pada kategori sangat tinggi, ada 6 peserta didik (16\%) memperoleh nilai pada rentang skor 80-89 pada kategori tinggi, ada 11 peserta didik (29\%) memperoleh nilai pada rentang skor 70-79 pada kategori sedang, dan ada 15 peserta didik (39\%) memperoleh nilai pada rentang 60-69 pada kategori rendah, serta 6 peserta didik (16\%) memperoleh nilai pada rentang 0-59 pada kategori sangat rendah. Sebaran hasil belajar peserta didik pada pertemuan pertama, bila dituangkan dalam bentuk diagram akan tampak seperti pada Gambar 6 berikut. 


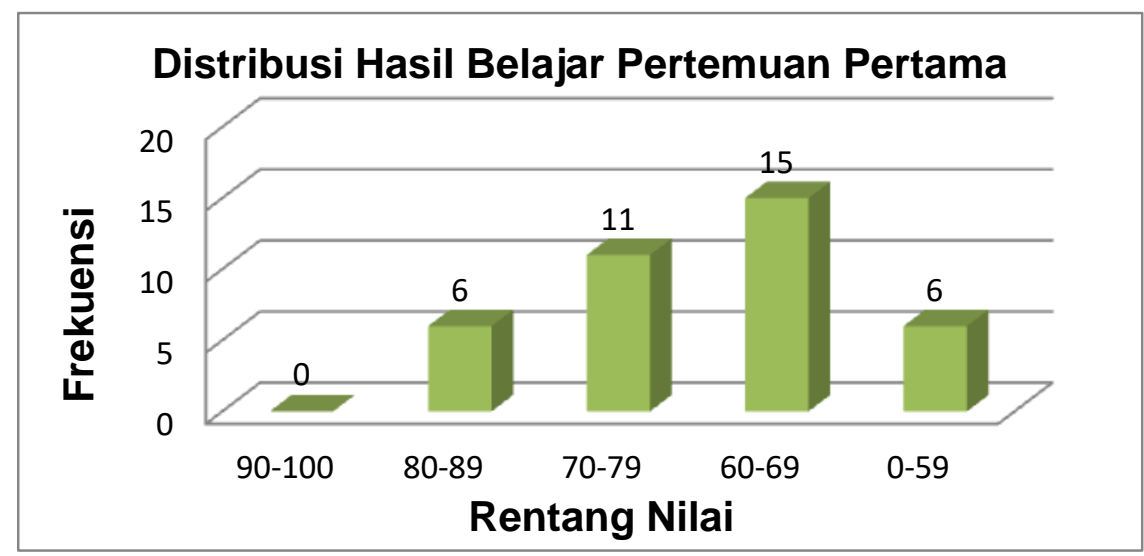

Gambar 6. Diagram Distribusi Hasil Belajar Pertemuan Pertama

Hasil belajar dari peserta didik kelas IV SD Negeri 1 Wirosari Kabupaten Grobogan yang rendah tersebut menunjukkan perlunya dilakukan sebuah inovasi dalam penggunaan multimedia pembelajaran agar hasil belajar meningkat.

Pertemuan kedua dilaksanakan pada hari Rabu tanggal 8 Agustus 2018 di SD Negeri 1 Wirosari kelas IV yaitu mata pelajaran PKn untuk menanamkan kesadaran konstitusi dan sikap toleransi. Hasilnya tersaji pada Tabel 6.

\begin{tabular}{lcccc}
\multicolumn{5}{c}{ Tabel 6. Distribusi Hasil Belajar Peserta Didik Pertemuan Kedua } \\
\hline \multicolumn{1}{c}{ Kategori } & Rentang Nilai & Frekuensi & Prosentase & Keterangan \\
\hline Sangat Tinggi & $90-100$ & 12 & $32 \%$ & Tuntas \\
Tinggi & $80-89$ & 14 & $37 \%$ & \\
Sedang & $70-79$ & 12 & $32 \%$ & \\
Rendah & $60-69$ & 0 & $0 \%$ & Tidak tuntas \\
Sangat Rendah & $0-59$ & 0 & $0 \%$ & \\
Jumlah & & 38 & $100 \%$ & \\
\hline
\end{tabular}

Berdasarkan distribusi hasil belajar peserta didik yang tersaji pada Tabel 6. mendiskripsikan bahwa hasil belajar pertemuan kedua dari 38 peserta didik kelas IV menunjukkan hasil sebaran sebagai berikut 38 peserta didik (100\%) tuntas belajar sesuai dengan KKM dan 0 peserta didik $(0 \%)$ belum tuntas belajar sesuai dengan KKM. Sebaran nilainya adalah 12 peserta didik (32\%) memperoleh nilai pada rentang skor 90-100 pada kategori sangat tinggi, 14 peserta didik (37\%) memperoleh nilai padarentang skor 80-89 pada kategori tinggi, dan ada 12 peserta didik 
(32\%) memperoleh nilai pada rentang skor 70-79 pada kategori sedang, dan tidak ada yang mendapat nilai di bawah 70 . Hasil belajar peserta didik pada pertemuan kedua, bila dituangkan dalam bentuk diagram akan tampak seperti pada Gambar 7.

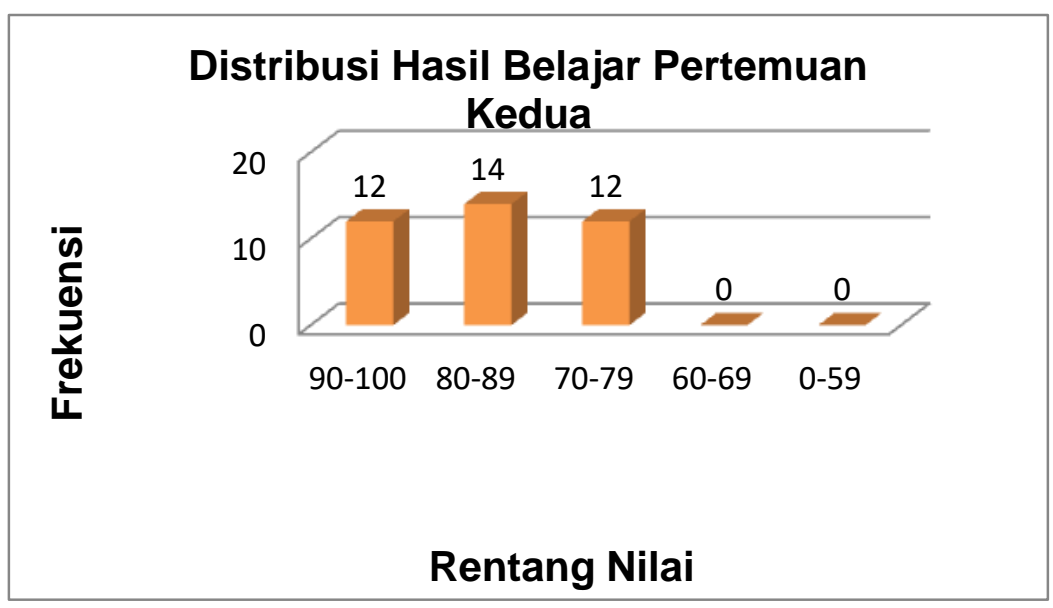

Gambar 7. Diagram Distribusi Hasil belajar Pertemuan Kedua

Berdasarkan pada Gambar 7 tampak bahwa hasil belajar 38 peserta didik pada pertemuan kedua paling banyak pada rentang nilai 80-89 terdapat 14 peserta didik. Pelaksanaan pembelajaran dapat digambarkan dengan langkah awal pembuatan rencana pembelajaran seperti pada Gambar 8.
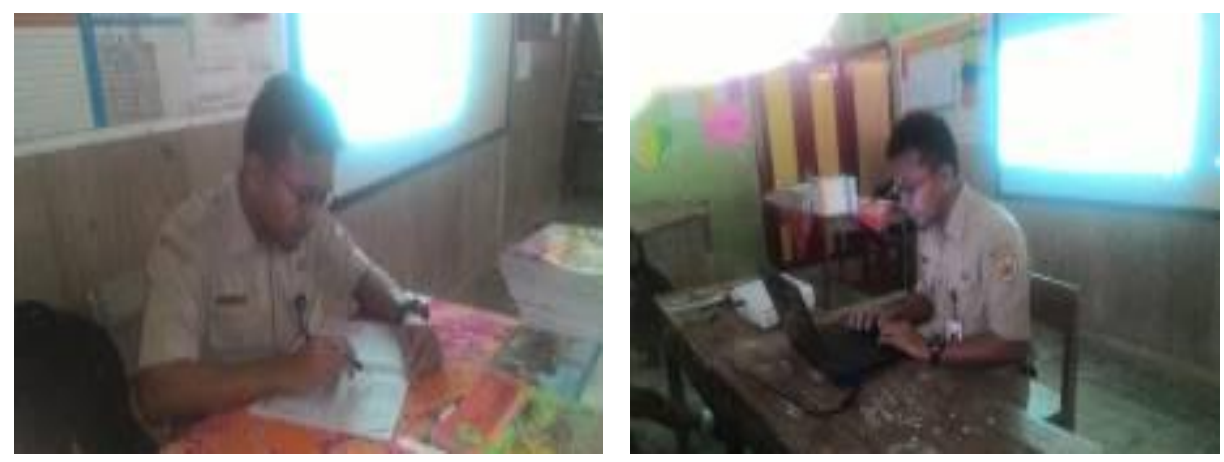

Gambar 8. Membuat Rencana Pembelajaran 


\section{Pembiasaan Kesadaran Berkonstitusi dan Sikap Toleransi di Luar Kelas}

Langkah selanjutnya adalah melakukan kegiatan pembiasaan kesadaran berkonstitusi dan sikap toleransi di luar kelas. Hal ini dikarenakan kegiatan menanamkan kesadaran berkonstitusi dan toleransi tidak hanya berakhir di dalam kelas, akan tetapi akan terus dikembangkan di luar kelas seperti yang terlihat pada Gambar 9. Kegiatan ini dilakukan melalui apersepsi dan tanya jawab dengan melatih kesadaran konstitusi dan menggunakan aplikasi android seperti yang terlhat pada Gambar 10. Pelaksanaan pembelajaran dengan penanaman kesadaran konstitusi dan sikap toleransi, seperti yang terlihat pada Gambar 11.
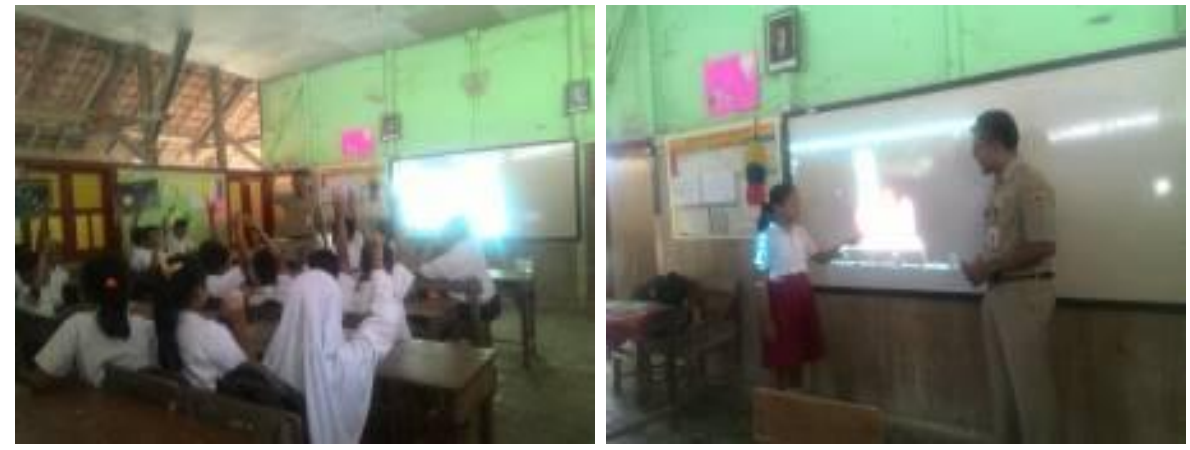

Gambar 9. Apersepsi dan Tanya Jawab
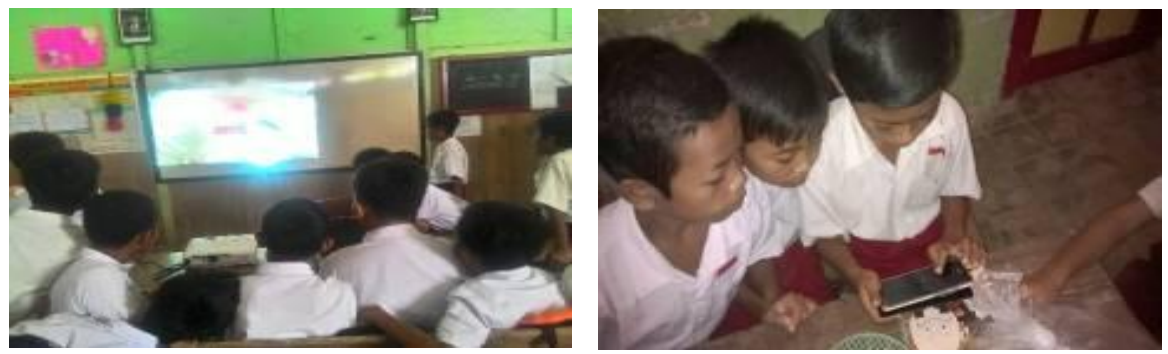

Gambar 10. Melatih Kesadaran Konstitusi dengan Menggunakan Aplikasi Android
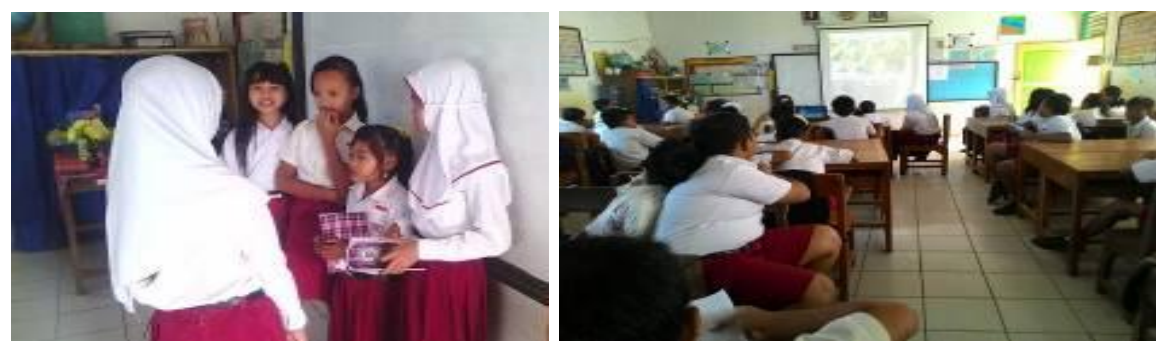

Gambar 11. Pelaksanaan Pembelajaran yang Menanamkan Kesadaran Konstitusi dan Sikap Toleransi 
Kegiatan menanamkan kesadaran berkonstitusi dan toleransi tersebut, antara lain (1) Melaksanakan doa bersama menjelang ujian. Orang tua dan peserta didik berbeda keyakinan saling mendukung dan mendoakan yang terbaik untuk semua; (2) Melaksanakan ekstrakurikuler Pramuka untuk meningkatkan rasa cinta tanah air, dan (3) Memanfaatkan perpustakaan sebagai sumber belajar. Kegiatan tersebut seperti terlihat pada Gambar 12, 13, dan 14.
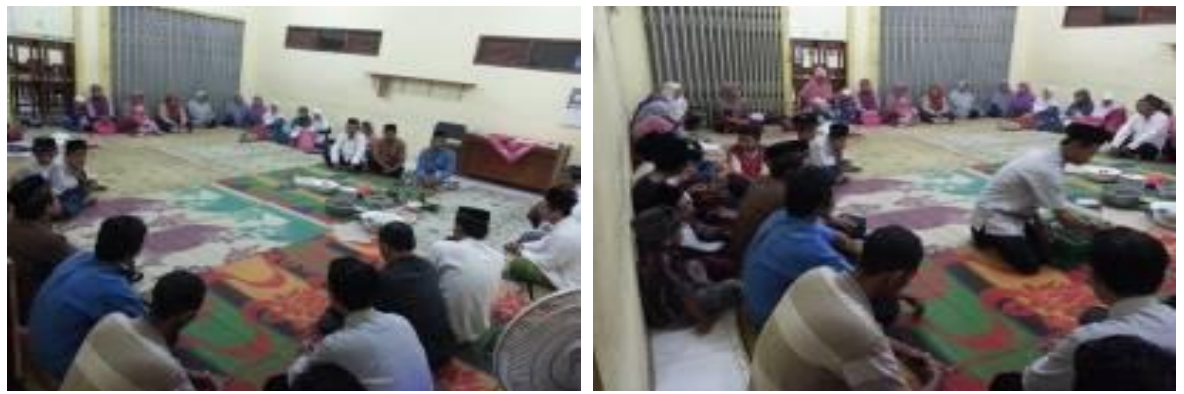

Gambar 12. Doa Bersama dengan Berbagai Umat Beragama Menjelang Ujian Nasional
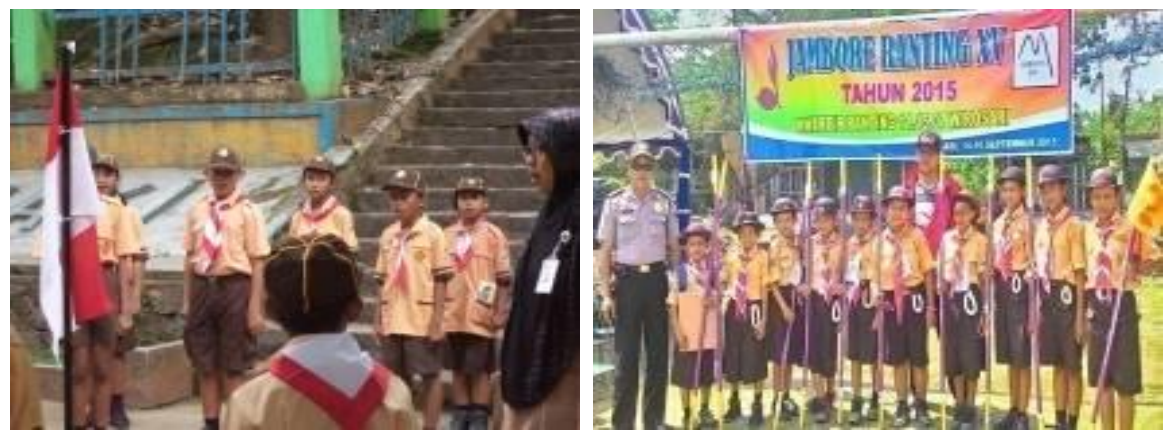

Gambar 13. Kegiatan Pramuka
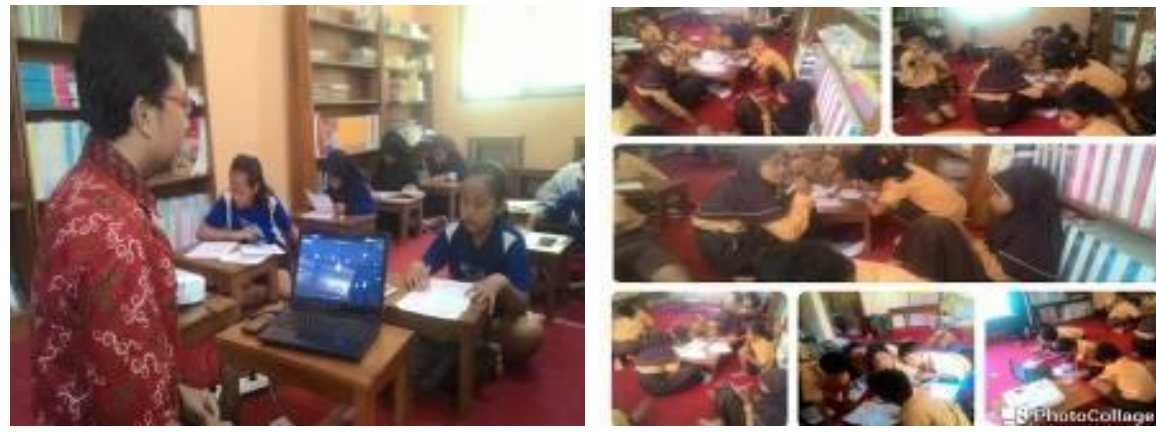

Gambar 14. Perpustakaan Sebagai Sumber Belajar 


\section{Hasil Penanaman Kesadaran Berkomunikasi dn Sikap Toleransi}

Setelah melaksanakan pembiasaan, langkah selanjutnya yaitu melakukan analisis hasil penanaman kesadaran berkonstitusi dan sikap toleransi dengan tersedianya perangkat dan media pembelajaran. Masukan dari rekan sejawat terhadap perangkat pembelajaran dan telah diperbaiki meliputi (1) konten kesadaran konstitusi dan sikap toleransi agar lebih mencakup materi yang cukup luas (telah diperbaiki); (2) apersepsi harus diperbaiki agar peserta didik dapat mengikuti alur kegiatan pembelajaran; dan (3) penulisan dan perbaikan huruf dan ejaan (telah diperbaiki).

Multimedia Lari Mesi mengombinasikan lagu tari dan games android dalam pembelajaran pendidikan kewarganegaraan. Awalnya peserta didik diajak untuk menyanyikan lagu dan sambil menari agar ada keterlibatan peserta didik dalam pembuatan media. Kemudian, mereka masuk dalam permainan games android. Games ini merupakan games bertingkat dari level 1 hingga ke 3. Tiap level mereka akan bermain permainan tentang Konstitusi Negara Kesatuan Republik Indonesia. Pada games akhir ke nada kuis sehingga peserta didik diajak mengingat kembali pelajaran yang telah diajarkan di sekolah berkaitan dengan konstitusi dan sikap toleransi. Multimedia Lari Mesi ini dapat digambarkan saat dibawa dan digunakan peserta didik, seperti yang terlihat pada Gambar 15.
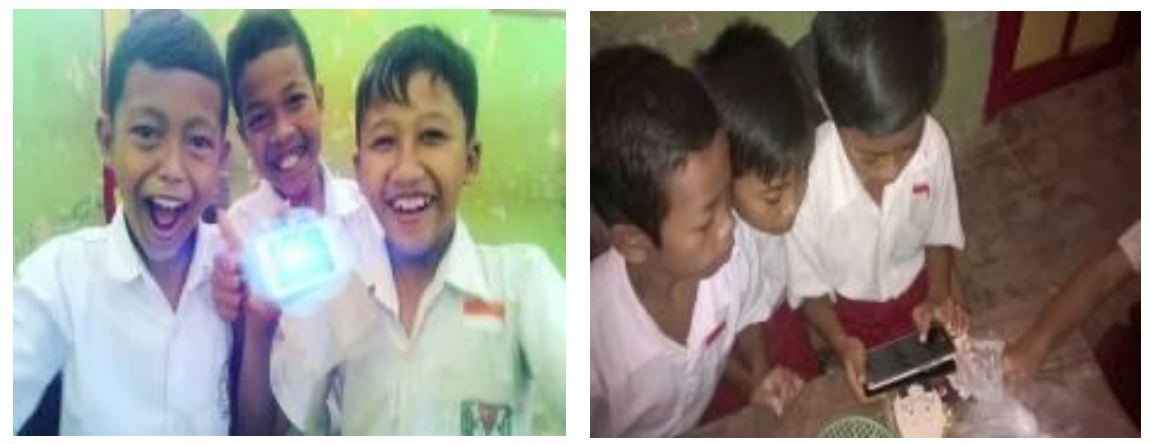

Gambar 15. Multimedia Lari Mesi

Dalam proses pengembangan multimedia Lari Mesi, dilakukan perbaikan berdasarkan masukan pakar media yang meliputi (1) tantangan 
dalam bermain games bisa dikembangkan agar lebih sesuai dengan permainan yang sedang trend; (2) games android memiliki kapasitas yang cukup berat untuk digunakan pada telepon genggam (HP) tertentu; (3) perlunya variasi gerakan dan tarian, seperti ajang pertunjukan agar peserta didik lebih tertarik dalam pembelajaran; dan (4) perlunya inovasi yang terus-menerus pada games anrdoid mengikuti perkembangan peserta didik pada jenjang tertentu.

\section{Hasil Pembelajaran Menanamkan Kesadasarn Konstitusi Peserta Didik dengan Multimedia Lari Mesi}

Setelah dilakukan implementasi pembelajaran menanamkan kesadaran konstitusi pada peserta didik menggunakan multimedia Lari Mesi dilakukan analisis hasil pembelajaran. Analisis dilakukan dengan membandingkan hasil belajar belajar siswa dengan dan tanpa menggunakan multimedia Lari Mesi. Data hasil belajar tersebut tersaji pada Tabel 7.

Tabel 7. Analisis Data dari Tiap Pembelajaran yang Dilakukan

\begin{tabular}{|c|c|c|c|c|c|}
\hline \multirow{3}{*}{ No } & \multicolumn{2}{|c|}{$\begin{array}{l}\text { Mata Pelajaran } \\
\text { Kelas / Semester } \\
\text { Kriteria Ketuntasan Mengajar }\end{array}$} & & $\begin{array}{l}\text { PKn } \\
\text { IV/ I } \\
70\end{array}$ & \\
\hline & \multirow{2}{*}{ Kategori } & \multicolumn{2}{|c|}{ Tanpa Lari Mesi } & \multicolumn{2}{|c|}{ Dengan Lari Mesi } \\
\hline & & Jumlah & $\%$ & Jumlah & $\%$ \\
\hline 1 & Tuntas & 17 & $45 \%$ & 38 & 100 \\
\hline 2 & Belum tuntas & 21 & $55 \%$ & 0 & 0 \\
\hline \multirow[t]{2}{*}{3} & Jumlah & 38 & 100 & 38 & 100 \\
\hline & Rata-rata & \multicolumn{2}{|c|}{64,47} & \multicolumn{2}{|c|}{81,58} \\
\hline
\end{tabular}

Berdasarkan tabel perbandingan hasil evaluasi tiap pertemuan, dapat dijelaskan bahwa pada pembelajaran tanpa media Lari Mesi adalah terdapat 21 peserta didik (55\%) yang belum tuntas dan sisanya, 17 peserta didik $(45 \%)$ telah tuntas dalam belajar. Nilai minimal pada pembelajaran tanpa menggunakan multimedia Lari Mesi adalah 50, sedangkan nilai maksimalnya 80. Hal ini menunjukkan bahwa tanpa menggunakan multimedia Lari Mesi, terdapat lebih dari sebagian peserta didik (55\%) yang belum mencapai ketuntasan hasil evaluasi peserta didik. Pada pembelajaran dengan menggunakan multimedia Lari Mesi terdapat 38 peserta didik (100\%) tuntas dalam pembelajaran dan tidak ada peserta didik yang tidak tuntas dalam 
pembelajaran (0\%). Apabila disajikan dengan diagram batang, distribusi hasil belajar tanpa dan dengan menggunakan multimedia Lari Mesi dapat dilihat seperti pada Gambar 16 berikut ini.

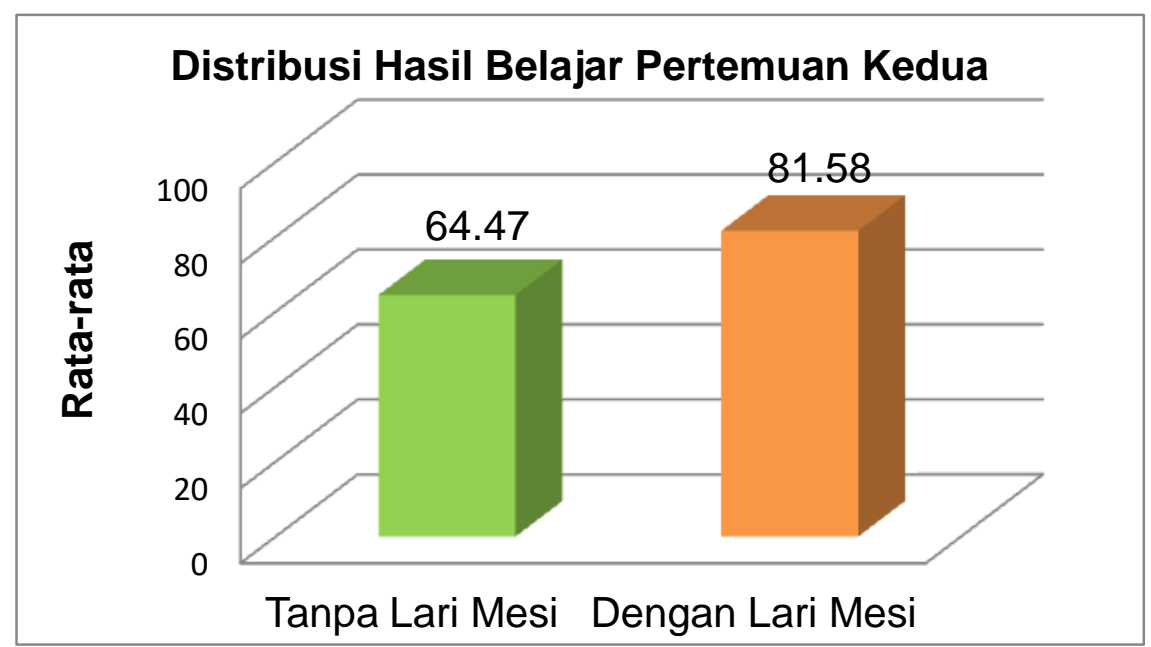

Gambar 16. Perbandingan Hasil Belajar Peserta Didik

Sedangkan, untuk kualitas hasil observasi peserta didik dan guru diketahui telah terjadi peningkatan kualitas pembelajaran, seperti yang tersaji padaTabel 8 terkait hasil observasi.

Tabel 8. Hasil Observasi

\begin{tabular}{cccl}
\hline No & Pertemuan & Hasil Observasi dalam Persen (\%) & Kriteria \\
\hline 1 & Pertemuan Pertama & $30,00 \%$ & Kurang \\
2 & Pertemuan Kedua & $89.71 \%$ & Sangat Baik \\
\hline
\end{tabular}

Berdasarkan data hasil observasi pada tabel 8 terbukti bahwa telah terjadi peningkatan kualitas pembelajaran, yaitu dari 30\% (kurang baik) pada pembelajaran sebelumnya menjadi $89,71 \%$ (sangat baik) pada pembelajaran dengan multimedia Lari Mesi.

\section{Peningkatan Kesadaran Berkonstitusi dan Sikap Toleransi}

Pembelajaran Pendidikan Kewarganegaraan tidak hanya dilaksanakan di dalam kelas, tetapi juga dapat dilakukan di rumah. Peserta didik menginstal aplikasi Lari Mesi di telepon genggam masing masing kemudian peserta didik dapat menunjukan dan memainkan games tersebut dengan keluarga di rumah yang dideskripsikan pada Gambar 17. 


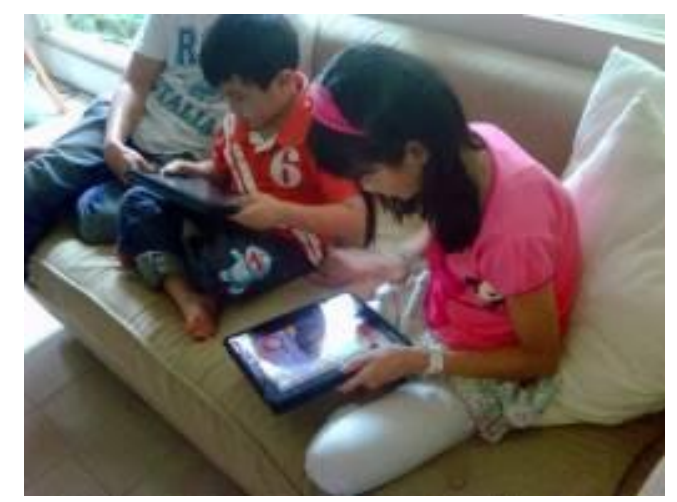

Gambar 17. Peserta Didik dan Orang Tua Melihat dan Memainkan Multimedia Lari Mesi

Penulis juga melakukan komunikasi dengan orang tua peserta didik secara tatap muka maupun dengan menggunakan SMS dan WhatsApp. Dari hasil komunikasi dengan orang tua peserta didik diketahui bahwa kesadaran berkonstitusi dan sikap toleransi beragama meningkat sesuai dengan apa yang diharapkan dari penggunaan multimedia Lari Mesi.

Mata pelajaran Pendidikan Kewarganegaraan terkadang hanya dimaknai guru sebagai pembelajaran yang bersifat sebagai hafalan semata. Materi Pendidikan Kewarganegaraan yang cukup padat memang memerlukan inovasi dan kreativitas karena harus bersifat konkrit untuk anak SD. Berdasarkan hal tersebut, diperlukan adanya media pembelajaran yang mampu mengatasi segala persoalan tersebut. Salah satu media pembelajaran yang mampu mengatasinya adalah media pembelajaran Lari Mesi yang merupakan aplikasi android penggabungan lagu tari dan games android. Media pembelajaran Lari Mesi menjadikan pembelajaran lebih interaktif dan tidak membosankan. Hal ini dapat terlihat dari hasil observasi pembelajaran guru yang menemukan adanya peningkatan yang signifikan dari kriteria kurang (30\%) sebelum menggunakan media Lari Mesi meningkat secara signifikan menjadi sangat baik $(89,71 \%)$ setelah menggunakan media tersebut.

Berdasarkan data hasil observasi, juga diketahui bahwa peserta didik masih belum mampu menemukan hubungan sebab akibat pada pembelajaran tanpa menggunakan media Lari Mesi. Namun, berubah 
menjadi lebih baik setelah menggunakan media Lari Mesi. Bahkan, hasil observasi dalam pembelajaran dengan menggunakan media Lari mesi menunjukkan hasil baik dan maksimal pada semua indicator yang diamati. Hal ini merupakan bukti bahwa media pembelajaran Lari Mesi memberikan hasil yang lebih baik dengan dibuktikan bahwa proses pembelajaran peserta didik telah mampu menanamkan kesadaran konstitusi dan sikap toleransi dalam kehidupan di sekolah dan masyarakat. Berdasarkan beberapa data hasil tersebut dapat disimpulkan bahwa proses pembelajaran PKn dengan menggunakan multimedia Lari Mesi telah berhasil menanamkan kesadaran berkonstitusi dan sikap toleransi dalam kehidupan anak anak.

\section{Penutup}

Simpulan yang dapat dirumuskan adalah pembelajaran PKn dengan menggunakan Lari Mesi dapat meningkatkan kesadaran konstitusi dan sikap toleransi pada peserta didik kelas IV SD Negeri 1 Wirosari semester 1 tahun ajaran 2020/ 2021. Penerapan Lari Mesi mampu membangkitkan kesadaran konstitusi dan sikap toleransi pada peserta didik SD Negeri 1 Wirosari. Perlu terus dikembangkan media pembelajaran berbasis game android yang disukai siswa untuk materi-materi lain dalam mata pelajaran PPKn mauun mata pelajaran lain agar peserta didik dapat belajar dengan senang.

\section{Ucapan Terimakasih}

Karya ilmiah ini dipersembahkan untuk kemajuan pendidikan di Indonesia, sehingga ucapan terimakasih kepada Kepala Dinas Pendidikan Pemuda dan Olahraga Kabupaten Grobogan serta kepada Kepala Sekolah Dasar Negeri 1 Wirosari atas kerja sama dan kolaborasi selama proses pengembangan hingga uji efektivitas melalui eksperimen di sekolah. Terima kasih tak hingga juga dihaturkan kepada wali murid yang telah berkolaborasi dan peran sertanya yang luar biasa dalam penggunaan media pembelajaran ini. Semoga media yang dikembangkan ini menginspirasi rekan guru dalam upaya meningkatkan kualitas pembelajaran. 


\section{Daftar Referensi}

BSNP. (2007). Peraturan Menteri Pendidikan Nasional Republik Indonesia Nomor 41 Tahun 2007 Tentang Standar Proses Untuk Satuan Pendidikan Dasar Dan Menengah.

Depdiknas. (2005). Materi Pelatihan Terintegrasi. Pendidikan Kewarganegaraan. Jakarta: Dirjen dikdasmen Direktorat Pendidikan Lanjutan Pertama.

Fonna, M., \& Mursalin, M. (2018). Role of Self-Efficacy Toward Students' Achievement in Mathematical Multiple Representation Ability (MMRA). Jurnal Ilmiah Peuradeun, 6(1), 31-40. doi:10.26811/peuradeun.v6i1.174

Hariyanto, B. (2020). Pengembangan Aplikasi Anola Berbasis Android untuk Pembelajaran Atletik Nomor Lari Jarak Pendek. Jurnal Didaktika Pendidikan Dasar, 4(2), 515-536. https://doi.org/10.26811/didaktika.v4i2.150

Ivan C. (2009). Langkah-langkah Mudah Membuat Game 3D. Yogyakarta: MediaKom.

Prasetyaningrum, E. W. (2020). Peningkatan Hasil Belajar Peserta Didik Konsep Pra Aksara Melalui Strategi Digital Pre-Historic Assesment. Jurnal Didaktika Pendidikan Dasar, 4(3), 655-676. https://doi.org/10.26811/didaktika.v4i3.128

Purwanto. (2013). Evaluasi Hasil Belajar. Yogyakarta: Pustaka Belajar.

Rolling, Andrew dan Ernest Adams. (2003). Game Design USA: New Riders Publishing.

Saminan, S., Risa, N., \& Hamid, T. (2017). Implementation of ARIAS Learning Model Integrated With Constructivist Theory to Improve Student Learning Outcomes. Jurnal Ilmiah Peuradeun, 5(2), 213-224. doi:10.26811/peuradeun.v5i2.124

Sudjana, Nana dan Ahmad Rivai. (2010). Media Pengajaran. Bandung: Sinar Baru Algensindo.

Sudjana, Nana. (2011). Dasar-Dasar Proses Belajar Mengajar. Bandung: Sinar Baru Algensindo.

Tabrani ZA. (2014). Dasar-Dasar Metodologi Penelitian Kualitatif. Yogyakarta: Darussalam Publishing. 
Walidin, W., Idris, S., \& Tabrani ZA. (2015). Metodologi Penelitian Kualitatif $\mathcal{E}$ Grounded Theory. Banda Aceh: FTK Ar-Raniry Press.

Wardani, Naniek Sulistya, dkk. (2012). Assesmen Pembelajaran SD: Bahan Belajar Mandiri. Salatiga: Widya Sari Press.

Wikipedia. (2017). Pengertian lagu. https://id.wikipedia.org/wiki/Lagu. diakses tanggal 10 Januari 2017 jam 22.35.

Wikipedia. (2017). Pengertian tari. https://id.wikipedia.org/wiki/Lagu. diakses tanggal 10 Januari 2021 jam 22.40.

Yusrizal, Y., \& Hanif, K. (2017). Increasing of Students' Motivation in Learning Physics Through the Use of Computer Simulation Media Viewed From Parents' Employment Background. Jurnal Ilmiah Peuradeun, 5(2), 201-212. doi:10.26811/ peuradeun.v5i2.129 